\title{
Molecular identification of sex in dioecious moss Nyholmiella obtusifolia (Orthotrichaceae) on the basis of ISSR markers
}

\author{
Monika Milewicz \& Jakub Sawicki
}

\begin{abstract}
Molecular identification of sex in dioecious moss Nyholmiella obtusifolia (Orthotrichaceae) on the basis of ISSR markers. - Čas. Slez. Muz. Opava (A), 60: 1-6, 2011.
\end{abstract}

\begin{abstract}
As far as an unisexuality in the animal kingdom is typical, in higher plants there most species are bisexual. Whereas in haploid bryophyte it can be noticed that dioecy in this group prevails. In the dioecious bryophyte a huge problem makes diagnostics of gender. Most dioecious mosses do not exhibit any discernible sexual dimorphism. The aim of present research was a finding genetic differences between two gender in the dioecious moss Nyholmiella obtusifolia with use of ISSR markers. This study was conducted on 16 individuals: 6 females (without sporophytes) and 10 randomly selected (unknown gender), what was dedicated by a very small number of sexexpressing plant material (rare sporophytes). Out of 12 ISSR primes using to this research, only 4 of them gave clear band patterns. There were: IS807, IS825, IS835 and IS840. The following results are based only on the amplification with ISSR 807 primer. It revealed the products of amplification, which seem to be typical for males and females, which sizes were approximately 600 $\mathrm{bp}$ for the former and $500 \mathrm{bp}$ for the latter. This study without doubt is the first trial of finding of genetic differences between females and males in dioecious moss Nyholmiella obtusifolia. This is the first step in development of sex-specific molecular marker for Nyholmiella obtusifolia. It is insomuch important, because it would be just the second moss, for which a molecular sex marker would be devised.
\end{abstract}

Key words: Nyholmiella obtusifolia, dioecious moss, DNA markers, sexual dimorphism, sterile

\section{Introduction}

As far as an unisexuality in the animal kingdom is typical, in plants there most species are bisexual. Only about 6\% of Angiospermae has got separated gender (Renner and Ricklefs 1995). Whereas in haploid bryophyte it can be noticed that dioecy in this group prevails. About $57 \%$ of moss species and $68 \%$ of liverworts are dioecious (Shaw and Goffinet 2000). An occurrence of gender became a starting point to the research on a sex ratio in natural populations and also induced to search for causes of such a gender distribution. A sex ratio in populations where a sexual dimorphism can be noticeable is quite easy to determine. A diagnostics of sex at an nearly stage of growth, when there are no flowers, can be some problem. However, a sexual dimorphism in higher plants is generally quite well discernible.

A completely different situation is in the dioecious bryophyte, where a huge problem makes here a diagnostics of gender. A sexual dimorphism is not in mosses well visible. Only a few species have got smaller males in comparison with females. This property is met in the following families: Dicranaceae, Leucobryaceae, Brachythecaceae and Orthotrichaceae (Shaw and Goffinet 2000). It sometimes happens that the differences between sizes of gametophyte are subtle (Shaw and Gaughan 1993), for instance in Orthotrichum lyellii (Vitt 1968) and then it is very hard to identify a sex in such a population.

Another helpful parameter in diagnostics of moss gender seems to be a size of spores. In literature there are some mentions that many dioecious mosses phenotypically express sex in the form of anisospory.This relationship is especially noticeable in family Orthotrichaceae. In this group, anisospory appears to be correlated with a reduction in the Y chromosome and also with reduction in size of the male gametophores. It is supposed that the smaller spores (microspores) are produced by males, and the bigger ones (macrospores) - by females. However, not always dioecy of bryophyte is dictated by a production of anisospores. For example, the dioecious Eurhynchium pulchellum produces only homospores (Vitt 1968). 
A good and probably the best determinant among the morphological markers, because giving a hundred per cent certainty of correct identification of gender, could be a presence of the sex organs: male- antheridia and female- archegonia. However, this index not always can be used to a sex identification, because not all of the individuals form them. It sometimes happens that the dioecious species of mosses reproduce vegetatively with the use of gemmae and it is unnecessary for them a production of the sex organs. These individuals are called sterile. Anderson i Lemmon (1974) showed that it is possibile that just only $10 \%$ of individuals in the same population produces the sex organs. Mishler i Oliver (1991) suggest that the females show more often a sex expression than the males. So all in all, determination of sex in the populations of mosses with the use of classical methods based on the observation can be impossible or a miscalculation. It is connected with the occurrence of steriles.

The sex identification with cytological level, which consists in a searching the morphologically differential sex chromosomes in the whole of chromosomal set, can also not be reliable. So far an existence of the heteromorphic sex chromosomes has only been reported among the liverworts: Sphaerocarpos donnellii (Allen 1917), Spaerocarpos texanus (Korpelainen 2008), Marchantia polymorpha (Bischler 1986) and in the mosses, genus Macromitrium (Ernst-Schwarzenbach 1944; Ramsay 1966). Therefore it appears that an effective method of sex identification in bryophyte has to be investigated on the genetic plane. The aim of present research was a finding genetic differences between two gender in the dioecious moss Nyholmiella obtusifolia with use of ISSR markers.

\section{Material and Methods}

The research were carry out on dioecious moss Nyholmiella obtusifolia. This is the most often occurred species in the family Orthotrichaceae, which has belonged to the genus Orthotrichum, subgenus Orthophyllum for long time. However, molecular studies showed evidently that two species: Orthotrichum obtusifolium and Orthotrichum gymnostomum are clearly distinct from other species of the genus Orthotrichum (Goffinet et al. 2004, Sawicki et al. 2009). These phylogenetic analysis clearly supported previous concepts (Hagen 1908) postulating that species of the subgenus Orthophyllum should be recognized as the separate genus Nyholmiella (Sawicki et al. 2010). The current name of genus Nyholmiella was proposed by Holmen and Warncke (Damsholt et al. 1969) and includes two species: Nyholmiella gymnostoma and Nyholmiella obtusifolia.

Nyholmiella obtusifolia and Nyholmiella gymnostoma may be distinguished from each other on the basis of the peristome, which is double in the former and lacking in the latter. Gametophytes of the two species are easily separated by leaf margins and cell papillosity: Nyholmiella gymnostoma has inrolled margins and two papillae per leaf cell surface while Nyholmiella obtusifolia has erect margins and unipapillose cell surfaces (Sawicki, unpublished).

Nyholmiella obtusifolia is widespread in the European continent (north to Svalbard), Greenland, the Caucasus, the Himalayas, Turkey, central and eastern Asia and North America. Populations of Nyholmiella obtusifolia occur in large number on the urbanized regions as well as in the natural forest ecosystems. This species is found in Poland very often, but in the herbarium collections there are only steriles. A population included in this research came from the part of Olsztyn city named Kortowo. A specificity of this population is an appearance of sporophytes (Sawicki, Plášek \& Szczecińska 2011), what was very important and useful in this study.

Total genomic DNA was extracted from fresh material representing 16 individuals: 6 females (without sporophytes) and 10 randomly selected (unknown gender). In order to avoid DNA contamination by fungi and other microorganisms, only fresh green parts of a gametophyte were taken, rinsed in distilled water and drained on an absorbent paper. DNA was isolated with ZR Plant/Seed DNA Kit TM (ZymoResearch) according to the manufacturer's instruction. Extracted DNA samples were stored at $-20{ }^{\circ} \mathrm{C}$.

In order to investigate genetic differences between females and males ISSR (Inter Simple Sequence Repeat) markers were used. The markers of this class show polymorphism of DNA fragments located between microsatellitary regions (Ziętkiewicz et al. 1994). The target sequences of ISSR markers does not require prior identification, which makes such markers suitable for species where species-specific primers amplifying microsatellite loci (Simple Sequence Repeat, SSR) have not been developed yet (Buczkowska et al. 2010). The ISSR primers used were the following: $807,810,813,816,819,822,825,831,834,835,840,846$ (see Table 1). 
The PCR reactions for ISSR markers were conducted in $20 \mu \mathrm{l}$ of reaction mixture containing $0.5 \mu l$ of the genomic DNA solution (40ng), $1 \mu \mathrm{M}$ primer, $1 \mu \mathrm{l}$ of BSA solution $(0.25 \mathrm{mg} / \mathrm{ml}), 0.3 \mu$ l Ultrapure dNTPs Set (EURx), $2 \mu 110$ x Pol Buffer B (EURx) and 1U YellowTaq polymerase (EURx).

PCR-ISSR reactions were performed as follows: (1) initial denaturation- 4 min. at $94{ }^{\circ} \mathrm{C}$, (2) denaturation$45 \mathrm{~s}$. at $94{ }^{\circ} \mathrm{C},(3)$ annealing- $50 \mathrm{~s}$. at $52^{\circ} \mathrm{C}$, (4) elongation- $1 \mathrm{~min} .30 \mathrm{~s}$. at $72{ }^{\circ} \mathrm{C}$, (5) final elongation- $7 \mathrm{~min}$. at $72{ }^{\circ} \mathrm{C}$. Stages 2-4 were repeated 40 times. The products of the ISSR- PCR reactions were separated on a $2 \%$ agarosegel, followed by DNA staining with ethidium bromide. After rinsing in deionized water, the agarose gel was analysed in transilluminator under UV light and photographed.

Table 1: Sequences of ISSR primers used in studies on N. obtusifolia with number of amplificated loci.

\begin{tabular}{|c|c|c|c|c|}
\hline Nr. & primer & sequence (5'-3') & bp & number of ampl. loci \\
\hline 1 & IS807 & AGAGAGAGAGAGAGAGT & 17 & 19 \\
\hline 2 & IS810 & GAGAGAGAGAGAGAGAT & 17 & smear \\
\hline 3 & IS813 & CTCTCTCTCTCTCTCTT & 17 & smear \\
\hline 4 & IS816 & CACACACACACACACAT & 17 & smear \\
\hline 5 & IS819 & GTGTGTGTGTGTGTGTA & 17 & smear \\
\hline 6 & IS822 & TCTCTCTCTCTCTCTCA & 17 & smear \\
\hline 7 & IS825 & ACACACACACACACACT & 17 & smear \\
\hline 8 & IS831 & ACCACCACCACCACCACC & 18 & smear \\
\hline 9 & IS834 & ATGATGATGATGATGATG & 18 & 25 \\
\hline 10 & IS835 & AGAGAGAGAGAGAGAGYC & 18 & smear \\
\hline 11 & IS840 & ACTTCCCCACAGGTTAACACA & 21 & 15 \\
\hline 12 & IS846 & GGGTGGGGTGGGGTG & 15 \\
\hline
\end{tabular}

\section{Results}

From among 12 ISSR primers tested in this research only 4 of them gave clear band patterns, without smears. There were the following primers: IS807, IS825, IS835 and IS840 (tab.1.). These successful primers allowed for amplification of 71 loci (17.75 loci per one primer on average). It was decided that PCR reactions with these primers would be repeated and the products of these amplifications would be electrophoretically separated for longer time and on the longer gel. In this way more clearly band patterns could be obtained. The present results are based only on the amplification with ISSR 807 primer. It is suggested to repeat PCR reactions with the rest of three ISSR primers and observe the received band patterns in search of genetic variability between females and males.

ISSR 807 primer revealed the products of amplification, which seem to be typical for males and females (Fig. 1 and Fig. 2), which sizes were approximately $600 \mathrm{bp}$ for the former and $500 \mathrm{bp}$ for the latter.

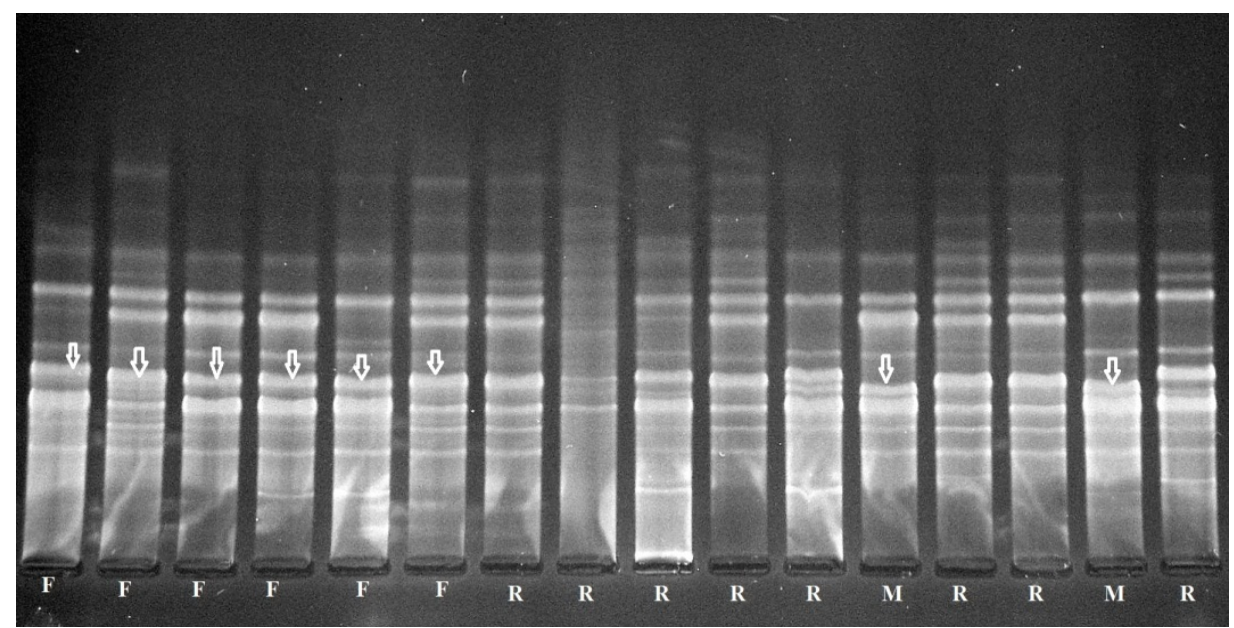

Fig 1: Amplification patterns of 6 females $(F)$, presumably 2 males $(M)$ and others randomly selected individuals (R) with primer ISSR 807. 


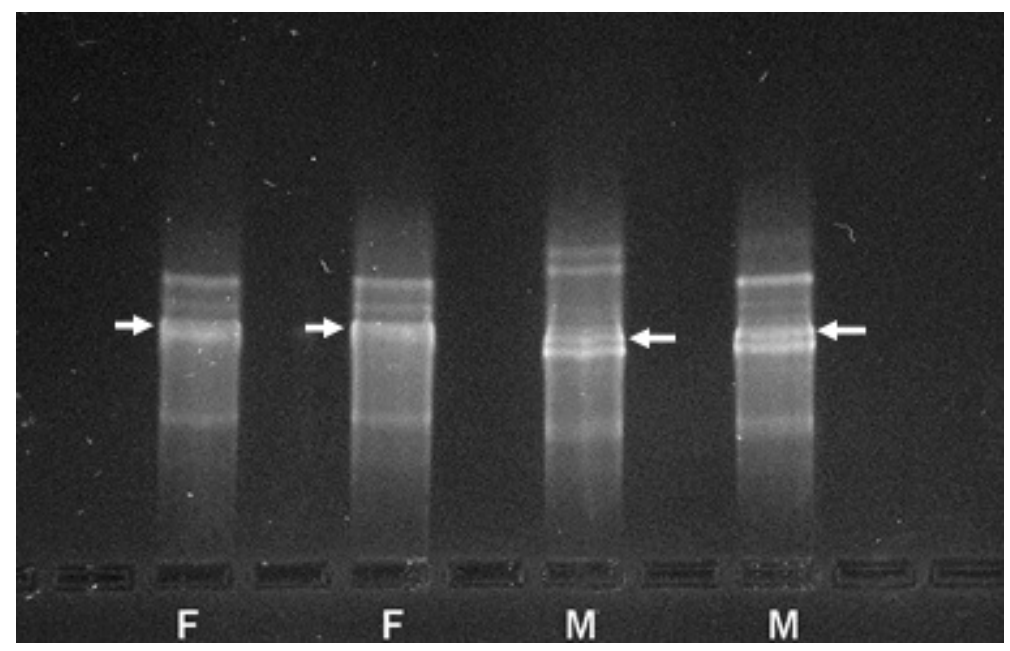

Fig 2: Fragment of amplification patterns with ISSR 807 primer showing significant differences between females and presumably males.

\section{Discussion}

This study without doubt is the first trial of finding of genetic differences between females and males in dioecious moss Nyholmiella obtusifolia. In this research, completely just like in Korpeleinen's studies (2008), only a few individuals were used due to a very small amount of sex-expressing plant material (rare sporophytes). The identification a genetic difference between two gender in this species may be called a big achievement. It results from poor, discernible sexual dimorphism. Vitt (1968) suggests that there is not any morphological dimorphism in this species and in addition to this spores of Nyholmiella obtusifolia are homomorphic. Farther a finding of archegonia and antheridia in this species is a rarity, because a vegetative reproduction is here common and an occurrence of sporophytes is an infrequent phenomenon (Sawicki, unpublished).

The obtained data are very optimistic, because they point DNA specific sequences both for females and males. The first genetic method for determination of sex in a moss (Pseudocalliergon trifarium) was developed by Korpelainen et al. (2008), but there only one sex-specific DNA marker (one sex-specific band) for females was found, whereas in males there was not any typical PCR- product identified. It is very disadvantageous, because a potential lack of amplification may not only follow an absence of complementary to primer sequence, but also degraded DNA or an existence of PCR- inhibitors. It is worth to notice that the same primer ISSR 807 revealed differences between females and males in Pseudocalliergon trifarium (Korpelainen et al. 2008) as well as in Nyholmiella obtusifolia,but the primers: IS810, IS816, IS819, IS822 and IS834 were failed in both cases. Korpelainen (2008) did not test the primers IS835 and IS840, whereas in this research screening with these primers is recommended in the further studies as well as primer IS825, which in research of Korpelainen was unsuccessful.

The present studies on identification of sex in mosses are just the second ones where ISSR-PCR analysis was applied. Previously this method was only used in Pseudocalliergon trifarium (Korpelainen et al. 2008). In the liverworts: Marchantia polymorpha (Fujisawa et al. 2001) and Sphaerocarpos texanus (McLetchie and Collins 2001) others methods were applied, namely Representational Difference Analysis (RDA) and Random Amplification of Polymorphic DNA (RAPD), respectively. The RAPD method, developed in 1990 (Williams et al.), was a technique the most often used to identify sex in various dioecious taxa (Ainsworth 2000). From 1994 (Ziętkiewicz et al.) more and more frequently ISSR method is applied. The ISSR technique is similar to RAPD, except that ISSR primers consist of di- or trinucleotide simple sequence repeat with a 5' or 3' anchoring sequence of 1-3 nucleotides. 
Compared with RAPD primers, the ISSR primer sequence is usually larger, allowing for a higher primer annealing temperature, which results in greater band reproducibility than RAPD markers (Culley and Wolfe 2000). In our work ISSR- PCR was shown to be effective for searching differences between two gender in Nyholmiella obtusifolia despite of low number of used primers. Testing of 12 ISSR primers was enough to find different band patterns. For comparison to detect genetic differences between females and males in Sphaerocarpos texanus with RAPD primers it was carried out PCR reactions with 238 different decamer primers (McLetchie and Collins 2001). ISSR technique is also useful in population genetic research, where level of genetic variation is low (Ziętkiewiczet al. 1994). It takes place in analysed population of Nyholmiella obtusifolia because of its preference of vegetative reproduction to sexual reproduction.

The presented studies are the first step in development of sex-specific molecular marker for Nyholmiella obtusifolia. It is insomuch important, because it would be just the second moss, for which a molecular sex marker would be devised. The sex-specific genetic markers are very desirable and useful tools. They allow not only to identify a plant gender at any stage in the life cycle, but also enable to conduct the research on sex ratio, which among the mosses are poor.

Acknowledgements: This study was made possible through financial support from the Ministry of Science and Higher Education (grant N303 416237).

\section{References}

Allen C. A. (1917): A chromosome difference correlated with sex differences in Sphaerocarpus.- Science, 46: 466-467.

Anderson L. E., Lemmon B. E. (1974): Gene flow distances in the moss, Weissia controversa Hedw.- Journ. Hattori Bot. Lab., 38: 67-90.

Bischler H. (1986): Marchantia polymorpha L. S. LAT. Karyotype analysis.- Journ. Hattori Bot. Lab., 60: 105-117.

Buczkowska K., Sawicki J., Szczecińska M., Klama H., Milewicz M., Bączkiewicz A. (2010): Genetic variation in the liverwort Bazzania trilobata inferred from ISSR markers.- Journal of Bryology, 32: 265- 274.

Cronberg N. (2002): Colonization dynamics of the clonal moss Hylocomium splendens on islands in a Baltic land uplift area: reproduction, genet distribution and genetic variation.- Journal of Ecology, 90: 925-935.

Cronberg N., Andersson K., Wyatt R., Odrzykoski I. J. (2003): Clonal distribution, fertility and sex ratios of the moss Plagiomnium affine (Bland.) T. Kop. in forests of contrasting age.- Journal of Bryology, 25: 155-162.

Culley T. M., Wolfe A. D. (2000): Population genetic structure of the cleistogamous plant species Viola pubescens Aiton (Violaceae), as indicated by allozyme and ISSR molecular markers.- Herdity, 86: 545-556.

Damsholt K., Holmen K., Warncke E. (1969): A list of the bryophytes of Denmark.- Botanisk Tidsskrift, 65: 163-183.

Ernst-Schwarzenbach M. (1944): La sexualité et la dimorphisme des spores des mousses.- Revue Bryol. Lichenol., 14: 105-113.

Fujisawa M., Hayashi K., Nishio T., Bando T., Okada S., Yamato K. T., Fukuzawa H., Ohyama K. (2001): Isolation of X and Y chromosome-specific DNA markers from a liverwort, Marchantia polymorpha, by Representational Difference Analysis.- Genetics, 159: 981-985.

Goffinet B., Shaw A.J., Cox C. J., Wickett N. J., Boles S. (2004): Phylogenetic inferences in the Orthotrichoideae (Orthotrichaceae: Bryophyta) based on variation in four loci from all genomes.Monographs in Systematic Botany from the Missouri Botanical Garden, 98: 270-289.

Hagen I. (1908): Forarbejdertil en norsklovmosflora. I. Orthotrichacea. Det Kongelige Norske Videnskabers Selskabs Skrifter, 13: 1-100.

Korpelainen H., Bisang I., Hedenäs L., Kolehmainen J. (2008): The first sex-specific molecular marker discovered in the moss Pseudocalliergon trifarium.- Journal of Heredity, 22: 1-7.

McLetchie D. N., Collins A. L. (2001): Identification of DNA regions specific to the X and Y chromosomes in Sphaerocarpostexanus.- Bryologist, 104: 543-547.

Mishler B. D., Oliver M. J. (1991): Gametophytic phenology of Tortula ruralis, a desiccation-tolerant moss, in the Organ Mountains of southern New Mexico.- Bryologist, 94: 143- 153. 
Newton M. E. (1971): A cytological distinction between male and female Mnium undulatum Hedw.Transactions of the British Bryological Society, 6: 230-243.

Ramsay H. P. (1966): The Hepaticae and Anthocerotae of North America. Vol. I Columbia Univ. Press. N. Y. $802 \mathrm{pp}$.

Renner S. S., Ricklefs R. E. (1995): Dioecy and its correlations in the flowering plants.- Am J Bot, 82: 596606.

Sawicki J., Plášek V., Szczecińska M. (2009a): Preliminary studies on the phylogeny of the genus Orthotrichuminffered from nuclear ITS sequences.- Annales Botanici Fennici, 46: 507-515.

- (2009b): Molecular evidence do not support the current division of the Orthotrichum subgenus Gymnoporus.Plant Systematics and Evolution, 279: 125-137.

- (2010): Molecular studies resolve Nyholmiella (Orthotrichaceae) as a separate genus.- Journal of Systematics and Evolution, 48(3): 183-194.

- (2011): Recent data on occurrence the sporophytes in populations of dioecious moss, Nyholmiella obtusifolia in North-Eastern Poland. - Čas. Slez. Muz. Opava (A), 60: 7-10, 2011.

Shaw A. J., Gaughan J. (1993): Control of sex ratio in haploid populations of the moss Ceratodon purpureus.- American Journal of Botany, 80: 584- 591.

Shaw J. A., Goffinet B. (2000): Bryophyte Biology. Cambridge University Press.

Une K. (1984): Sexual dimorphism in some Japanese species of Macromitrium.- Journ. Hattori Bot. Lab., 56:123- 132.

Williams J. K. G., Rubelik A. R., Livak K. J., Rafalski A., Tingey S. V. (1990): DNA polymorphisms amplified by arbitrary primers are useful as genetic markers.- Nucleic Acids Res, 18: 6531- 6535.

Vitt D. H. (1968). Sex determination in mosses.- Mich Bot, 71: 195- 203.

Ziętkiewicz E., Rafalski A., Labuda D. (1994): Genome fingerprinting by simple-sequence repeat (SSR) anchored polymerase chain reaction amplification.- Genomics, 20: 176- 183.

Authors' addresses: Monika Milewicz \& Jakub Sawicki, Department of Botany and Nature Protection, University of Warmia and Mazury in Olsztyn, Plac Łódzki 1, 10-727 Olsztyn, Poland (corresponding author's e-mail: jakub.sawicki@uwm.edu.pl) 